\title{
Tuotantogeenien hienokartoitus kanalla
}

Mervi Honkatukia ${ }^{1}$, Maria Tuiskula-Haavisto ${ }^{1}$, Dirk-Jan DeKoning ${ }^{2}$, Asko Mäki-Tanila ${ }^{1}$ ja Johanna Vilkki $^{1}$

${ }^{I}$ MTT, Maa-ja elintarviketalouden tutkimuskeskus, Kotieläintuotannon tutkimus, Eläinjalostus,31600Jokioinen, etunimi.sukunimi@mtt.fi

${ }^{2}$ Roslin Institute, Roslin, Midlothian EH25 9PS, U.K, dj.dekoning@bbsrc.ac.uk

\section{Johdanto}

Jalostusvalinta on perinteisesti pohjautunut kvantitatiiviseen genetiikkaan, jossa tilastotieteen menetelmin mallinnetaan ja ennustetaan valinnan vaikutuksia. Kotieläinten perinnöllisen muuntelun tutkiminen sai uutta ulottuvuutta, kun tuotanto-ominaisuuksia sääteleviä geenejä (QTL) alettiin kartoittaa DNA-markkerikarttojen ja sitä varten tehtyjen tilastotieteellisten sovellusten avulla. QTL-kartoituksella saadulla tiedolla voidaan tehostaa perinnöllistä edistymistä - markkereita käyttämällä valinta voidaan kohdistaa suoraan ominaisuuden perinnölliseen osaan ilman häiritseviä ympäristövaikutuksia.

Viime vuosien uraauurtava työ QTL-alueiden paikantamisessa onkin tuottanut rohkaisevia tuloksia; kanoilta on löydetty kromosomialueita, joihin kytkeytynyt muuntelu vaikuttaa merkitsevästi jalostettaviin ominaisuuksiin. Tähän mennessä saadut tulokset ovat QTL:n sijainnin määrityksessä vielä suuntaa-antavia. Hienokartoitus QTL-alueiden rajaamiseksi on tarpeen, jotta tuloksia voitaisiin hyödyntää jalostusvalinnassa.

Useat tutkimusryhmät ovat raportoineet QTL-alueista, jotka vaikuttavat tärkeisiin tuotanto-ominaisuuksiin kuten kasvuun, painoon ja tautien vastustuskykyyn. Kananmunan laadulliset ominaisuudet ovat kuitenkin jääneet vähemmälle huomiolle, vaikka niiden merkitys taloudellisesti on huomattava. Valkuaisen tehtäviin kuuluu mm. pitää keltuainen paikallaan ja toimia mikrobeja tuhoavana 'väliaineena'. Huonolaatuinen, vetinen valkuainen sallii keltuaisen liikahtelun munan sisällä mahdollistaen keltuaisen kosketuksen kuoreen. Ulkopuolinen mikrobisto läpäisee huokoisen kuoren helposti. Näin vieras mikrobisto pääsee tunkeutumaan aina keltuaiseen asti. Tästä on seurauksena erilaiset infektiot, jotka heikentävät munan säilyvyyttä. Huonolaatuinen, rikkinäinen kuori edesauttaa tätä prosessia.

Alustavassa koko kanan perimän kattavassa kartoituksessa löytyi 20 kananmunan laatuun tai tuotanto-ominaisuuksiin vaikuttavaa aluetta. Esimerkiksi kromosomista 4 löytyi alue, joka vaikuttaa sekä kanan että munan painoon ja rehunkulutukseen. Kuoren kestävyyteen vaikuttavia alueita löytyi kahdesta, munan valkuaisen vetisyyteen kolmesta eri kromosomista (2, 4 ja 8). Valkuaisen vetisyyteen vaikuttavista QTL-alueista lupaavin, kromosomi 2 valittiin ensimmäiseksi hienokartoitettavaksi alueeksi. Kartoitettavalta alueelta tyypitettiin lisää markkereja ja rekombinaatioyksilöitä tuotettiin lisää takaisinristeytysaineiston avulla.

\section{Aineisto ja menetelmät}

Kanan QTL-kartoituksen tutkimusaineisto kerättiin vuosina 1994-1999. Kartoituspopulaation aikaansaamiseksi risteytettiin kaksi toisistaan poikkeavaa munijakanalinjaa: ruskea Rhode Island Red (RIR) ja valkoinen White Leghorn (WL). RIR-linjan munat olivat kuoreltaan kestävämpiä, mutta valkuaisen laadultaan heikompia kuin WL-linjan. Eroja löytyi myös muista tuotanto-ominaisuuksista, mutta ennen kaikkea linjat erosivat geneettisellä tasolla. Isovanhempien eli sukupolven $\mathrm{G}_{0}$ valintakriteerinä pidettiin ainoastaan valkuaisen laatua. Molemmista linjoista valittiin kaksi kukkoa ja kanaa risteytettäväksi. Seuraavasta sukupolvesta $\left(\mathrm{G}_{1}\right)$ valittiin 8 kukkoa ja 32 kanaa (2 kukkoa ja 8 kanaa jokaisesta neljästä 'perheestä') sukupolven $\left(\mathrm{G}_{2}\right)$ vanhemmiksi. Risteytys tehtiin molemminpuoleisesti 
(resiprookkisesti), jotta myös sukupuolen vaikutus ominaisuuksiin tulisi huomioitua. Kolmesta haudontaerästä saatiin $307 \mathrm{G}_{2}$-polven kanaa. Hienokartoitusta varten takaisinristeytettiin $\mathrm{G}_{2}$-polven kanoja puhtaiden linjojen kukkojen $\left(\mathrm{G}_{0}\right)$ kanssa. Jälleen käytettiin risteytettävien kanojen valinnassa laatuominaisuuksia.

Kaikki sukupolvet kuuluivat tuotantotarkkailuun, jossa mitattiin munantuotantoa ja painoa, rehunkulutusta, sekä valkuaisen että kuoren laatua. Valkuisen laatua mitattiin erikseen alkutuotantokaudella (40 viikon iässä) ja loppumunintakaudella (60 viikon iässä).

Ensimmäisessä vaiheessa kanan genomi oli analysoitu 99 mikrosatelliittimarkkerilla. Kartoitus kattoi 14 kytkentäryhmää, 1842 cM:n pituudelta (noin 2/3 kanan genomista). Hienokartoitusvaiheessa markkeritiheyttä kasvatettiin; kromosomiin 2 kartoitettiin 7 uutta markkeria alkuperäisten 13 lisäksi. Uudet markkerit keskitettiin QTL-alueelle. Käytetyt markkerit olivat mikrosatelliittimarkereita ja alueella sijaitsevasta kandidaattigeenistä (vimentin) löytynyt muuntelu SNP-markkerina (single nucleotide polymorphism). Takaisinristeytysaineistosta valittiin tutkimukseen mukaan vain ne perheet, joista löytyi muuntelua valkuaisen laadun suhteen.

Markkereista laadittiin kytkentäkartta käyttämällä CRIMAP -ohjelmaa (Green ym. 1990). Kytkentäanalyysi tehtiin monen markkerin regressiolla käyttämällä 'QTL Express' ohjelmaa (http:/qtl.cap.ed.ac.uk/, Seaton ym. 2002) ja aineistoa varten räätälöityä ohjelmaa (Tuiskula-Haavisto ym. 2002).

\section{Tulokset}

Kromosomista 2 löytyi alustavassa koko genomin kartoituksessa alkutuotantokauteen vaikuttava QTL-alue. Tämä alue tarkentui hienokartoituksessa ja saman alueen todettiin vaikuttavan myös loppumunintakauden valkuaisen laatuun. Tilastoanalyysien mukaan kromosomissa 2 sijaitsee kaksi valkuaiseen laatuun vaikuttavaa aluetta $(32-54 \mathrm{cM}$ ja $137 \mathrm{cM})$. Molemmat geenit vaikuttavat ominaisuuteen sekä alku- että loppumunintakaudella.

\section{Johtopäätökset}

Hienokartoitus tarkensi aikaisemmin löydettyä valkuaisen vetistymiseen vaikuttavaa QTLaluetta. Lisäksi näyttää siltä, että kromosomissa 2 on kaksi erillistä (sekä alku- että loppumunintakaudella vaikuttavaa) QTL-aluetta sadan senttimorganin pituisella alueella. Vimentiini-geeni ei vaikuttanut valkuaisen vetistymiseen, vaikkakaan sen osallisuutta epäsuoraan säätelyyn ei voida sulkea pois. QTL-alueilla sijaitsee vertailevan kartoituksen perusteella useita tunnettuja geenejä, jotka voisivat olla vetistymisen takana: olisi mahdollista lähteä yksi kerrallaan sulkemaan pois niiden osuutta.

\section{Kirjallisuus:}

Green P, Falls K. and Steve Crooks. 1990. CRI-MAP documentation version 2.4 (http://linkage.rockefeller.edu/soft/crimap/)

Seaton G, Haley CS, Knott SA, Kearsey M, Visscher PM. 2002. QTL Express: mapping quantitative trait loci in simple and complex pedigrees. Bioinformatics. 18(2):339-40.

(http:/qtl.cap.ed.ac.uk)

Tuiskula-Haavisto M, Honkatukia M, Vilkki J, de Koning D.J, Schulman N.F, MäkiTanila A. 2002. Mapping of quantitative trait loci affecting quality and production traits in egg layers. Poultry Sci. 81:919-927. 
SUOMEN MAATALOUSTIETEELLISEN SEURAN TIEDOTE NRO 19

Vanhala, T., Tuiskula-Haavisto, M., Elo, K., Vilkki, J. and Mäki-Tanila, A. 1998.

Evaluation of genetic variability and genetic distances between eight chicken lines using microsatellite markers. Poultry Sci. 77: 783-790. 